\title{
Post Mortem Interval: Necrobiome Analysis Using Artificial Neural Networks
}

\author{
Khenchouche Abdelhalim $^{1,2, *}$, Bouharati Khaoula ${ }^{2}$, Bouharati Saddek ${ }^{1,3}$, Mahnane Abbas ${ }^{2}$, \\ Hamdi-Cherif Mokhtar ${ }^{2}$ \\ ${ }^{1}$ Depatment of Microbiology, Faculty of Natural Science and Life, UFAS Setif1 University, Setif, Algeria \\ ${ }^{2}$ Laboratory of Health and Environment, Faculty of Medicine, UFAS Setifl University, Setif, Algeria \\ ${ }^{3}$ Department of Electronics, Laboratory of Intelligent Systems, UFAS Setif1 University, Setif, Algeria
}

\section{Email address:}

vicedoyenpedagogie@outlook.com (K. Abdelhalim), bouharatik@gmail.com (B. Khaoula), sbouharati@univ-setif.dz (B. Saddek), mahnanea@yahoo.fr (M. Abbas)

*Corresponding author

\section{To cite this article:}

Khenchouche Abdelhalim, Bouharati Khaoula, Bouharati Saddek, Mahnane Abbas, Hamdi-Cherif Mokhtar. Post Mortem Interval: Necrobiome Analysis Using Artificial Neural Networks. Computational Biology and Bioinformatics. Vol. 5, No. 6, 2017 , pp. $90-96$. doi: $10.11648 /$ j.cbb.20170506.13

Received: October 5, 2017; Accepted: October 18, 2017; Published: December 8, 2017

\begin{abstract}
Aims: In criminal investigations, it is necessary to determine the date and time of the death of a person. Different techniques are used. In this study, we try to analyze the necrobioma that characterizes all the bacteria that populate a corpse. It would be necessary to determine which bacteria first inhabit a dead organism? Which bodies are the first organs to be affected? Which microorganisms will tend to multiply post-mortem? How to establish a dynamics of bacterial diffusion and an occupation gradient according to the moment of death? Several factors are involved in this dynamic. Mathematical modeling becomes very complex. In this study, we propose an intelligent system to predict the exact date of death of the number and species found at time (t). Materials and Methods: The purpose is to determine and enumerate the bacterial colonies in the study organ. Establish the bacterial dynamics as a function of time. In this study, an artificial neural network is established. The input variables are bacterial species, their growth rates, growth conditions (temperature, humidity, soil type, and bacterial species). The rate of bacterial species in specified organ is considered as output variable. The time taken for a bacterial species to reach this rate under defined conditions determines the date of death of the person. Results: Since input variables are considered complex, uncertain, an artificial neural network demonstrates its ability to solve such complexity. After the learning phase of the network from the real data, this creates a function of correspondence between the space of inputs and output. The established system makes it possible to instantly read the time elapsed after death from the introduction of the random values at the input with the maximum precision. The proposed system remains extensible to enter variables that may have an effect on the output.
\end{abstract}

Keywords: Necrobiome, Microbial Dynamics, Post Mortem, Intelligent Systems, ANN

\section{Introduction}

In order to evaluate the post mortem interval (PMI), different techniques are used in criminal investigations. The PMI estimation accuracy decreases with time since death [1]. Forensic entomology is often the most used. However, the evaluation error is significant. Several factors influence the process of decomposition of the corpse. In this context, microbiology can provide an alternative method in the estimation of the PMI [2]. Bacteria offer the opportunity to monitor their dynamics. For example, the bacteria that inhabit the skin and the mouth follow a consistent trend during the process of decomposition of the corpse [3]. Some eight million bacterial species per gram of soil are involved in the decomposition process and play the role of recyclers of human remains [4]. The ecological factors are then to be taken into account in order to improve the estimation of the PMI [5]. The microbial population of the soil has a great 
influence in this dynamic [6]; [7]; [8]; [9]. To this is added the acceleration of decomposition in the soil by the arthropods [10-11].

In this study, we propose an intelligent system to predict the exact date of death of the number and species found at time $(\mathrm{t})$. The purpose is to determine and enumerate the bacterial colonies in the study organ. Establish the bacterial dynamics as a function of time. An artificial neural network is established. The input variables are bacterial species, their growth rates, growth conditions (temperature, humidity, soil type, and bacterial species). The rate of bacterial species in specified organ is considered as output variable. The correspondence between this bacterial level and the time elapsed since the beginning of the process; define the duration of this growth which will define the time of death of the person. The proposed system combines the input variables with the output variable which expresses the time of death of the person.

\section{Role of Microbes}

Much of the literature focuses on microbial activity surveys in severe soils and has shown that bacteria are useful biomarkers for forensic pathology [12]; [13]; [14]; [15]; [16]; [17]; [18]. But in general, few studies are devoted to the role of bacteria in the decomposition of dead bodies, whatever their role [19]; [20]; [21]; [22]; [23]. The studies carried out in this field mainly concern the resulting decomposition of microorganisms and microenvironments [24]; [25]; [26]. By analyzing a number of bacteria involved in the first phase of swelling of the body, a transformation of aerobic bacteria (Staphylococcus and Enterobacteriacae) into anaerobic bacteria (Clostridia and Bacteroides) was found [27]; [28]; [29]; [30]. But the soil taxa associated with the decomposition of the carcass have not been carefully examined. In addition to soil decomposers, the carcasses carry a commensally dense microbial community (Microbiome) which is likely to be introduced into the soil as progress decomposition. We know that commensally microorganisms mediate initial tissue decomposition days after death [31-32]. Despite our belief that bacteria play a major role in the recycling of organic matter resulting from carcasses, our knowledge of responsible bacterial communities is limited [33].

\section{Factors Involved}

The factors involved are complex. Some factors are biotic and other additional abiotics [34-37]. The evolution of all the factors involved in post mortem is very difficult to define. Various environmental factors have their effect. This is a biomolecular process. After chemical or biochemical degradation, the accompanying energy exchange can generate new organisms. This whole system becomes very unstable [38]. In addition to this, it is necessary to associate soil ecology which is also poorly understood. If the effect of soil temperature and soil type is evident, other factors may be involved that require experimental research [39]. The example of an obese person keeps the body temperature longer than a thin person [40]. From this point on, the complexity of the phenomenon appears. Each soil has its properties. The proliferation of microbial communities differs from summer to winter. All this must be taken into account in forensic investigations [34]. A corpse decomposes more rapidly in contact with the ground, so that any separation between the body and the earth delays its decomposition [41]. According to the nature of the garments and their thickness, the decomposition varies. The effect of clothing role is to protect the larvae which accelerate decomposition [42]. Clothes made of natural materials are more degradable by microorganisms in contrast to those made of artificial materials [43]. Light also has its effect, from which it can be noted that the decomposition is slower when the tomb is deeper. By way of comparison, corpses buried at a depth of 30 to $60 \mathrm{~cm}$ can reach the bone state after a few months, while those buried at a depth of 90 to $120 \mathrm{~cm}$ require a year to reach this stage [44]. The microbial population is also limited by the oxygen concentration [45]; [46]. Funeral conditions also have their effects. They can retain moisture released from decaying tissue [47]. The dispersion of the components which promote decomposition is increased by the tightness of the coffin for example [48].

In general, studies devoted to environmental factors such as temperature and humidity, which are parameters that make the study of decomposition very complex, are limited. The dynamics of microorganisms in soil is paramount in human decomposition [49]; [50]. Moreover, what makes the system even more complex and the task of forensic investigations more complicated is the conditions that precede death. A subject having an abnormality in its body temperature resulting from heat stroke, for example, or a fever or a stressed subject or having hyperthyroidism, neuroleptic drugs, sepsis, or brain injury or malignant hyperthermia, and also the presence in its body of drugs or toxins, all this disrupts the conditions of decomposition. A physical effort before death also influences his body temperature. The age of the person is also a parameter to be taken into account [51]; [52].

\section{Techniques}

Different techniques are used in the estimation of the PMI in crime investigations and re-enactment of the crime. These methods are categorized as quantitative or subjective, or if there are independent variables or assumptions [53]. If the estimate of (PMI) is a necessity in forensic investigations [54], then it is necessary to develop a standard technique. In this context, attempts to develop universal techniques applicable everywhere are trying to impose themselves nowadays. But the problems of geographic differences that are specific to each region make this impossible. So any method must be tested in each region before being applied in forensic investigations [55].

Developing a method is no small thing, because infinity 
of variables influences the rate of decomposition of a corpse [56]. Since the search for intrinsic microbial factors related to pre-death diseases varies from one person to another, some models suggest the use of profiling techniques [57]. If in the United States algorithms have been developed, they remain not applicable to other regions of the world [58]. Some of these techniques use genomic analyzes because the microbial species that inhabit the soil and have a role to play in decomposition are about $10^{3}$ to $10^{6} \mathrm{species} / \mathrm{g}$ of soil [59].

\section{Artificial Neural Networks}

Biology has brought a lot of information about the functioning of the brain, neurons ...etc. Mathematicians then tried to reproduce the functioning of the brain by integrating this knowledge in biology into computer programs, and giving them the possibility of 'learn. Artificial neural networks currently find a variety of applications in the field of science and technology [60]. However, artificial neural networks have the dynamics and the ability to read experimental data from the real environment and are therefore able to solve the complex systems of biophysical processes. Neural networks are systems learning to perform functions of mapping between two spaces, input space and output space.

As long as the parameters characterizing the effects of bacteria on the decomposition of the human body are characterized by imprecision and complexity, we found that the analysis of these factors by artificial neural networks is adequate [61].

About the parameters involved in the decomposition, we consider the inputs of the system [Temperature, humidity, soil type, and bacterial species]. The rate of bacterial species in specified organ is considered as output variable. It is then necessary to establish a correspondence between this bacterial level and the time elapsed since the beginning of the process. This goes back to the date of the person's death. Table 1 .

- The bacterial species are coded in equivalent numbers $(1 ; 2 ; 3)$. Where 1,2 and 3 correspond to bacterial species studied.

- The growth rate of bacteria resulting in the organ is encoded in number equivalents $(1 ; 2 ; 3)$. Where 1,2 and 3 correspond to rates scaled in three levels.

- The number nature of soil is coded in equivalent numbers $(1 ; 2 ; 3)$. Where 1,2 and 3 correspond to three natures of soil in favor of bacterial growth, moderately favorable or unfavorable.

Table 1. Input and output variables of the neural system.

\begin{tabular}{|c|c|c|c|c|}
\hline Bacteriaspecies & $\mathbf{T}\left({ }^{\circ} \mathbf{C}\right)$ & Humidity(\%) & NatureofSoil & Growthrate \\
\hline 1 & 0 & 30 & 1 & 1 \\
\hline 1 & 5 & 40 & 1 & 1 \\
\hline 1 & 10 & 50 & 1 & 1 \\
\hline 2 & 15 & 60 & 2 & 2 \\
\hline 2 & 20 & 70 & 2 & 2 \\
\hline 2 & 25 & 75 & 2 & 2 \\
\hline 3 & 30 & 80 & 3 & 3 \\
\hline 3 & 35 & 85 & 3 & 3 \\
\hline
\end{tabular}

Learning the neural network

By entering the values at the input corresponding to the result recorded at the output of the system, the network establishes a linking function between the two spaces. By varying the values at input and output, the system performs a readjustment of the function by modifying mathematical coefficients called weight. After a large number of combinations, by repeating the operation, the readjustment of the function continues until the system has the smallest possible error value.

Note: it is not necessary to change the system in each case, but just work on the weights [W]. Since these weights are for each neuron (the sum is weighted), it is possible to modify the network by modifying their values without changing the network itself. Figure 1.

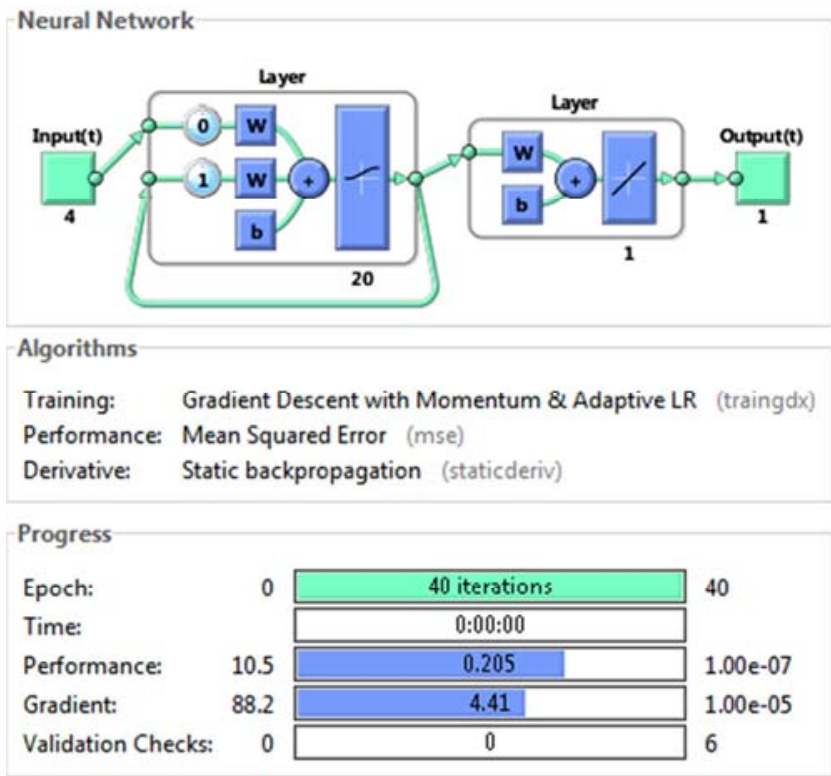

Figure 1. Block diagram of the system. 


\section{Results}

After assigning several values to the input and output of the system, and after learning the network, this one gets to an optimal readjustment after 40 iterations. With the learning rate 0.005 at 40 epoc, the performance of $10^{-7}$ is achieved with a gradient of $10^{-5}$ Figure 2,3 .

N Neural Network Training Performance (plotperform), Epoch 40, Maximum epoch....

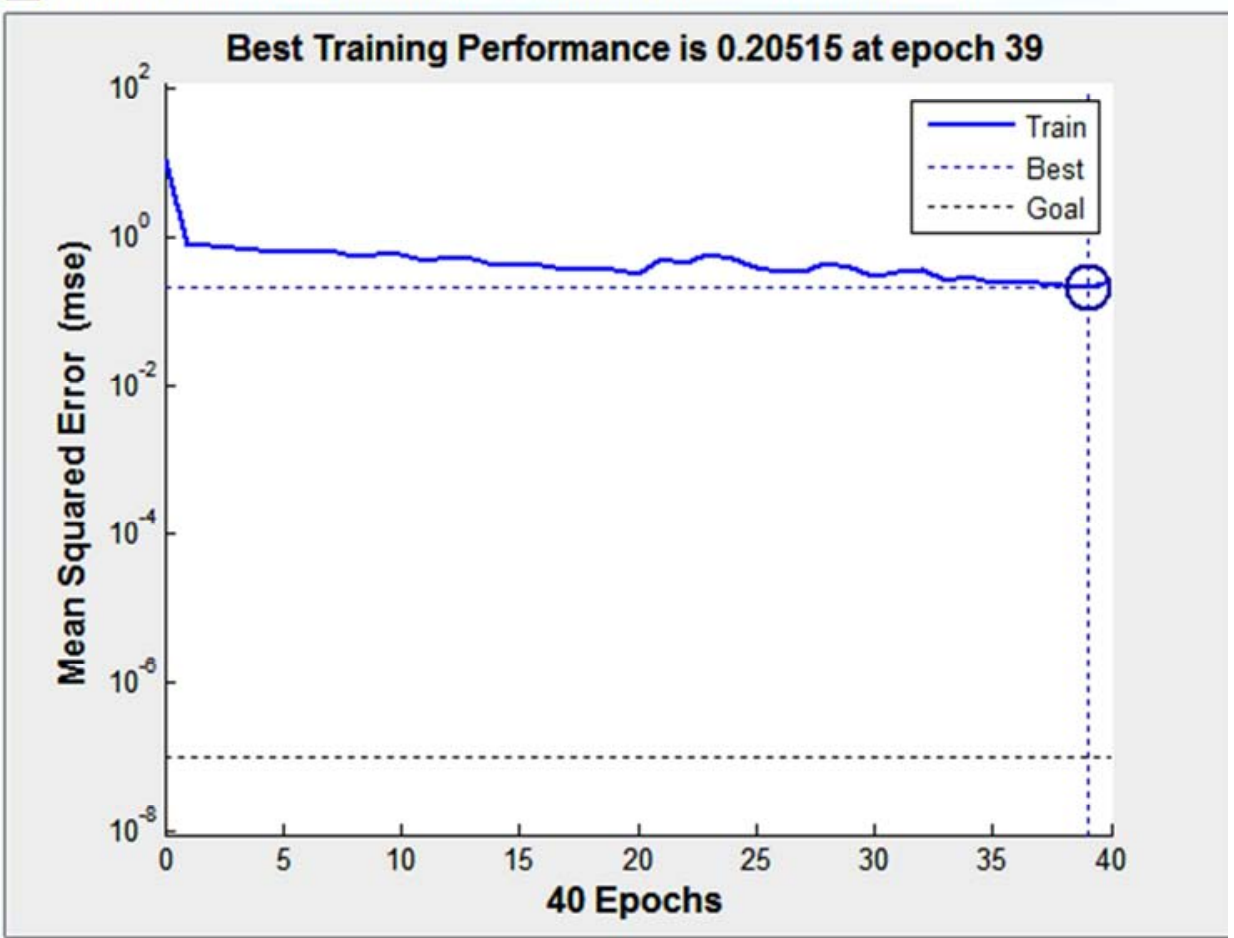

Figure 2. Optimum at 40 epocs.

1. Neural Network Training Training State (plottrainstate), Epoch 40, Maximum ep... \begin{tabular}{l|l|l|l|}
\hline & $\square$ \\
\hline
\end{tabular}

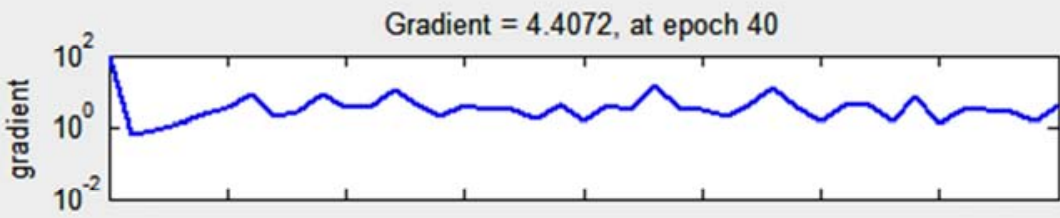

Validation Checks $=0$, at epoch 40

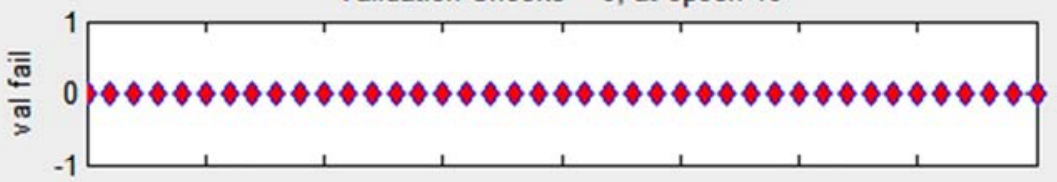

Learning Rate $=0.0050847$, at epoch 40

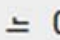

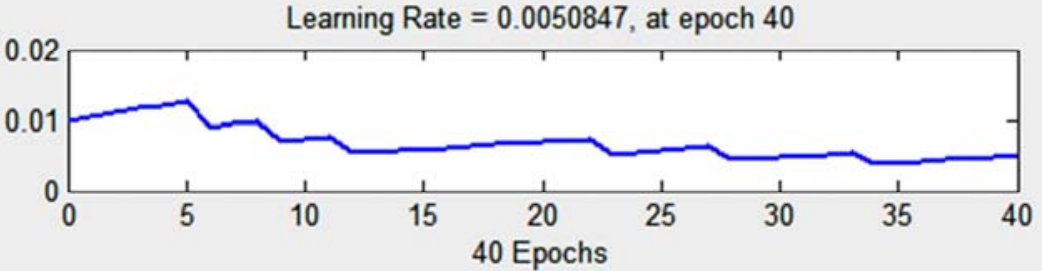

Figure 3. Training results. 


\section{Conclusions}

The process of decomposition of a human body after its death is subject to several factors. Some are intrinsic such as age, weight, pre-mortem conditions such as the presence of trauma, drugs or toxins. Other factors are extrinsic such as environmental factors, temperature and humidity, exposure to the open air, sunlight, types and layers of clothing, coffin quality, depth of burial, access to incest ... etc. In fact, the conditions of the corpse are often diverse, complex. Therefore, it is very difficult to compare studies and real cases because we have differences in climate, geographic location, subject or model used.

The analysis of like factors using artificial neural networks demonstrates its ability to resolve such variables. Each bacterial species has specific growth conditions. We have made the correspondence between the two input spaces (the factors that intervene in the growth of each species) and output that expresses the resulting growth rate of bacteria. After the learning phase of the network it became possible to read the growth rate of bacteria that informs us about the time taken by these bacteria to develop and thus the date of the death of the person.

\section{References}

[1] Kaliszan, M., Hauser, R. \& Kernbach-Wighton, G. Estimation of the time of death based on the assessment of post mortem processes with emphasis on body cooling. Legal Medicine. 2009. 11(3): 111-117.

[2] Metcalf et al. Jessica L Metcalf et al. A microbial clock provides an accurate estimate of the postmortem interval in a mouse model system. 2013. eLife; 2:e01104. DOI: 10.7554/eLife.01104.

[3] Pechal JL, Crippen TL, Benbow ML, et al. The potential use of bacterial community succession in forensics as described by high throughput metagenomic sequencing. Int $\mathrm{J}$ Legal Med. 2013. doi: 10.1007/s00414-013-0872-1.

[4] Vass A. A. Beyond the grave-understanding human decomposition. Microbiol Today 2001. 28:190-192.

[5] Mondor E. B, Tremblay MN, Tomberlin JK, et al. The ecology of carrion decomposition. Nat Educ Knowledge 2012. 3:21.

[6] Hyde ER, Haarmann DP, Lynne AM, et al. The living dead: bacterial community structure of a cadaver at the onset and end of the bloat stage of decomposition. 2013. PLoS One 8, e77733. doi:10.1371/journal.pone.0077733.

[7] Hyde ER, Haarmann DP, Petrosino JF, et al. Initial insights into bacterial succession during human decomposition. Int $\mathrm{J}$ Legal Med 2015. 129:661-671.

[8] Metcalf JL, Wegener Parfrey L, Gonzalez A, et al. A microbial clock provides an accurate estimate of the postmortem interal in a mouse model system. 2013. ELife 2, e01104. doi:10.7554/eLife.01104

[9] Weiss, S, Carter DO, Metcalf JL, Knight R. Carcass mass has little influence on the structure of gravesoil microbial communities. Int J Legal Med. 2015. doi:10.1007/s00414015-1206-2.
[10] Payne J. A summer carrion study of the baby pig Sus Scrofa Linnaeus. Ecology 1965. 46:592-602. doi:10.2307/1934999

[11] Pechal JL, Crippen TL, Benbow ME, et al. The potential use of bacterial community succession in forensics as described by high throughput metagenomic sequencing. Int J Legal Med 2014. 128:193-205. doi:10.1007/s00414-013-0872-1.

[12] Carter DO, Yellowlees D, Tibbett M Temperature affects microbial decomposition of cadavers (Rattus rattus) in contrasting soils. Faculty Publications. Department of Entomology. 2008.

[13] Pechal J, Crippen T, Benbow ME, et al. The potential use of bacterial community succession in forensics as described by high throughput metagenomic sequencing. International Journal of Legal Medicine: 2013. 1-13.

[14] Hopkins DW, Wiltshire PEJ, Turner BD. Microbial characteristics of soils from graves: an investigation at the interface of soil microbiology and forensic science. Applied Soil Ecology 2000. 14: 283-288.

[15] Howard GT, Duos B, Watson-Horzelski EJ. Characterization of the soil microbial community associated with the decomposition of a swine carcass. International Biodeterioration \& Biodegradation 2010. 64: 300-304.

[16] Melvin JR, Jr., Cronholm LS, Simson LR, Jr., Isaacs AM. Bacterial transmigration as an indicator of time of death. $J$ Forensic Sci 1984. 29: 412-417.

[17] Dickson GC, Poulter RTM, Maas EW, Probert PK, Kieser JA. Marine bacterial succession as a potential indicator of postmortem submersion interval. Forensic Science International 2011. 209: 1-10.

[18] Caporaso JG, Kuczynski J, Stombaugh J, et al. QIIME allows analysis of high-throughput community sequencing data. Nat Methods 2010. 7: 335-336.

[19] Carter DO, Yellowlees D, Tibbett M. Temperature affects microbial decomposition of cadavers (Rattus rattus) in contrasting soils. Faculty Publications. Department of Entomology. 2008.

[20] Evans WED. The Chemistry of Death. Springfield IL: Charles C. Thomas. 1963.

[21] Janaway R, Percival S, Wilson A. Decomposition of Human Remains. In: Percival S, Microbiology and Aging: Humana Press. 2009. pp. 313-334.

[22] Pechal J, Crippen T, Benbow ME, et al. The potential use of bacterial community succession in forensics as described by high throughput metagenomic sequencing. International Journal of Legal Medicine: 2013. 1-13.

[23] Vass A. Beyond the Grave - Understanding Human Decomposition. Microbiology Today 2001. 28: 190-192.

[24] Hopkins DW, Wiltshire PEJ, Turner BD. Microbial characteristics of soils from graves: an investigation at the interface of soil microbiology and forensic science. Applied Soil Ecology 2000. 14: 283-288.

[25] Howard GT, Duos B, Watson-Horzelski EJ. Characterization of the soil microbial community associated with the decomposition of a swine carcass. International Biodeterioration \& Biodegradation 2010. 64: 300-304. 
[26] Stokes KL, Forbes SL, Tibbett M. Freezing skeletal muscle tissue does not affect its decomposition in soil: Evidence from temporal changes in tissue mass, microbial activity and soil chemistry based on excised samples. Forensic science international 2009. 183: 6-13.

[27] Evans WED. The Chemistry of Death. Springfield IL: Charles C. Thomas. 1963.

[28] Janaway R, Percival S, Wilson A. Decomposition of Human Remains. In: Percival S, Microbiology and Aging: Humana Press. 2009. pp. 313-334.

[29] [Vass A. Beyond the Grave - Understanding Human Decomposition. Microbiology Today 2001. 28: 190-192.

[30] Melvin JR, Jr., Cronholm LS, Simson LR, Jr., Isaacs AM. Bacterial transmigration as an indicator of time of death. $\mathrm{J}$ Forensic Sci 1984. 29: 412-417.

[31] Heimesaat MM, Boelke S, Fischer A, et al. Comprehensive postmortem analyses of intestinal microbiota changes and bacterial translocation in human flora associated mice. 2012. PLoS One.; 7: e40758. doi: 10.1371/journal.pone.0040758 PMID: 22808253.

[32] Swann LM, Forbes SL, Lewis SW. Analytical separations of mammalian decomposition products for forensic science: A review. Analytica Chimica Acta. 2010. 682: 9-22. doi: 10.1016/j.aca.2010.09.052 PMID: 21056711.

[33] Cobaugh KL, Schaeffer SM, DeBruyn JM. Functional and Structural Succession of Soil Microbial Communities below Decomposing Human Cadavers. 2015. PLoS ONE 10(6): e0130201. doi:10.1371/ journal.pone.0130201

[34] Carter DO, Metcalf JL, Bibat A, Knight R. Seasonal variation of postmortem microbial communities. Forensic Sci Med Pathol 2015. 11:202-227. doi:10.1007/s12024-015-9667-7

[35] Benbow ME, Pechal JL, Lang JM, et al. The potential of highthroughput metagenomic sequencing of aquatic bacterial communities to estimate the postmortem submersion interval. J Forensic Sci 2015. doi:10.1111/1556-4029.12859

[36] Benbow ME, Lewis AJ, Tomberlin JK, Pechal JL. Seasonal necrophagous insect community assembly during vertebrate carrion decomposition. J Med Entomol 2013. 50:440-450. doi:10.1603/ME12194.

[37] Tomberlin JK, Mohr R, Benbow ME, et al. A roadmap for bridging basic and applied research in forensic entomology. Annu Rev Entomol 2011. 56:401-421. doi:10.1146/ annurevento-051710-103143.

[38] Powers RH. The decomposition of human remains. In: Rich J, Dean DE, Powers RH, editors. Forensic medicine of the lower extremity. Totowa: The Humana Press; 2005. p. 3-15.

[39] David O. Carter, David Y. and Mark T. Temperature affects microbial decomposition of cadavers (Rattus rattus) in contrasting soils Applied Soil Ecology 2008. 40:1 pp. 129137; doi: 10.1016/j.apsoil.2008.03.010.

[40] Smart, J. L. \& Kaliszan, M. The post mortem temperature plateau and its role in the estimation of time of death: A review. Legal Medicine 2012. 14(2): 55-62.

[41] Duday, H. \& Guillon, M. Understanding the circumstances of decomposition when the body is skeletonized. In Forensic
Anthropology and Medicine: Complimentary Sciences from Recovery to Cause of Death, edited by Schmitt, A., Cunha, E. \& Pinheiro, J. Totowa: Humana Press Inc. 2006. pp. 117-157.

[42] Kelly JA, Van Der Linde TC, Anderson GS. The influence of clothing and wrapping on carcass decomposition and arthropod succession during the warmer seasons in Central South Africa. J Forensic Sci. 2009. 54(5): 1105-12.

[43] Prangnell J, McGowan G. Soil temperature calculation for burial site analysis. Forensic Sci Int. 2009. 191(1-3): 104-9.

[44] Chee H. T., Sri P., Amir H., et al. Post mortem changes in relation to different types of clothing Malaysian J Pathol; 2013. 35(1): $77-85$.

[45] Dent, B., Forbes, S. \& Stuart, B. Review of human decomposition processes in soil. Environmental Geology 2004. 45(4): 576-585.

[46] Statheropoulos, M., Agapiou, A., Zorba, E., et al. Combined chemical and optical methods for monitoring the early decay stages of surrogate human models. Forensic Science International 2011. 210(1): 154-163.

[47] Fiedler S, Graw M. Decomposition of buried corpses, with special reference to the formation of adipocere. Naturwissenschaften. 2003. 90(7): 291-300.

[48] Ross, A. H. \& Cunningham, S. L. Time-since-death and bone weathering in a tropical environment. Forensic Science International 2011. 204(1): 126-133.

[49] Goff ML. Early post-mortem changes and stages of decomposition in exposed cadavers. Exp Appl Acarol 2009. 49:21-36. doi:10. 1007/s10493-009-9284-9

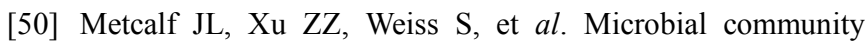
assembly and met.abolic function during mammalian corpse decomposition. Science 2015. aad2646.

[51] Adams, V. I. Medicolegal autopsy and postmortem toxicology. In Handbook of Autopsy Practice, edited by Waters, B. L. Totowa: Humana Press Inc. 2009b. pp. 125-136.

[52] [52]. Smart, J. L. \& Kaliszan, M. The post mortem temperature plateau and its role in the estimation of time of death: A review. Legal Medicine 2012. 14(2): 55-62.

[53] Madea, B. Is there recent progress in the estimation of the postmortem interval by means of thanatochemistry? Forensic Science International. 2005.151(2-3): 139-150.

[54] Forbes S. Time since death: a novel approach to dating skeletal remains. Aust J Forensic Sci. 2004. 36(2):67-72.

[55] Stephanie J. M, Paul F, Shari L. et al. Estimating post-mortem interval using accumulated degree-days and a degree of decomposition index in Australia: a validation study, Australian Journal of Forensic Sciences, 2015. DOI: 10.1080/00450618.2015.1021378.

[56] Mann R, Bass W, Meadows L. Time since death and decomposition of the human body: variables and observations in case and experimental field studies. J Forensic Sci. 1990; 35(1):103-111.

[57] Eilizabeth K. Costello et al. Bacterial Community Variation in Human Body Habitats Across Space and Time Science 2009. 326, 1694; DOI: 10.1126/science.1177486. 
[58] Rhine S, Dawson J. Estimation of time since death in the south western United States. In: Reichs K, editor. Forensic Osteology: advances in the identification of human remains. Springfield, IL: Charles C. Thomas; 1998. p. 145-159.

[59] Finley S. J. et al. Microbial Signatures of Cadaver Gravesoil During Decomposition Microb Ecol. 2016. DOI 10.100/s00248-015-0725-1
[60] Brion G. M, Neelakantan T. R, Lingireddy S. A neuralnetwork-based classification scheme for sorting sources and ages of fecal contamination in water. Water research. 2002. 36 (15), 3765-3774.

[61] Bouharati S., Benamrani H., Alleg F., et al. Artificial Neural Networks In Prevention Of Nosocomials Infections. International journal of scientific \& technology research 2013. volume 2 , issue 10 . 